\title{
RESEARCH ON SINGLE-LEAF WALLS MADE WITH LIGHTENED CLAY BRICKS
}

\author{
MANUEL C. JUÁREZ ${ }^{1 *}$, M $^{\text {a }}$ PILAR MORALES ${ }^{2,3}$, PEDRO MUÑOZ ${ }^{4}$, PABLO \\ OLASOLO \\ ${ }^{1}$ Universidad de La Rioja, Escuela Técnica Superior de Ingenieria Industrial, C/Luis de \\ Ulloa 20, 26004-Logroño, La Rioja, Spain \\ ${ }^{2}$ Universidad Autónoma de Chile, Facultad de Ingenieria, Av. Pedro de Valdivia 641 - \\ Providencia, Santiago - Chile \\ ${ }^{3}$ Research Group: Modelación Matemática Aplicada a la Ingenieria (MOMAIN), \\ Universidad Internacional de La Rioja (UNIR), Gran Via Rey Juan Carlos I 41; \\ 26002-Logroño, La Rioja, Spain \\ ${ }^{4}$ Universidad Autónoma de Chile, Facultad de Ingenieria, 5 Poniente 1670 Talca- \\ Chile
}

\begin{abstract}
This paper explains the studies conducted on the subject by RADEB (Research and Development in Energy and Buildings) Research Group at the University of La Rioja. The aim of this work is to study the possibility of improving the thermal transmittance of a single-leaf wall made with lightened clay bricks. A first aspect is to study the possibility of lightening the clay by using additives, reducing the clay's conductivity without decreasing its resistive ability. The internal and external geometry of the bricks has been studied by the Finite Element Method (FEM). Different wall assemblies with these bricks have been studied.
\end{abstract}

Keywords: lightened clay brick, thermal transmittance, single-leaf walls, energy efficiency

\section{INTRODUCTION}

Buildings today are not ecologically sustainable. They do not respect their surroundings and are detrimental to the environment, due to the high consumption of energy resources resulting in a large amount of harmful atmospheric emissions [1].

Buildings consume a vast amount of thermal energy. In fact, the residential and tertiary sectors account for approximately $26.8 \%$ of the total energy consumed in EU-28, which amounts to 478.6 million-ton oil equivalent (Mtep) [2]. Much of this energy is used for the heating and air conditioning of buildings.

This study aims to optimize the energy efficiency of a particular type of enclosure that is increasingly used on buildings: single-leaf enclosures with low-density materials, known as lightened materials. The quality of the enclosures determines the amount of energy required to provide the target thermal comfort design.

\footnotetext{
* Corresponding author, email: manuel.juarez@unirioja.es

(C) 2016 Alma Mater Publishing House
} 
Recent studies have reported the impact these wall-cladding materials on buildings have on $\mathrm{CO}_{2}$ emissions, and their energy performance [3]. Other studies have reported on the influence the porous structure of clay bricks has on improving the enclosure's thermal features [4].

A single-leaf enclosure consists of a single leaf, without an air chamber. The lightened ceramic blocks used in this case have good acoustic insulation, high mechanical resistance, and an exceptional resistance to fire, with remarkable insulation properties and thermal comfort (thermal inertia) [5].

In Spain, following the entry into force of the Technical Building Code (CTE, in its Spanish initialism), efforts are being made to adapt domestic legislation to the Community Directives on energy efficiency in buildings to bring it in line with the legislation of other Member States. The Code's adoption in 2006 involved a significant change for building materials. The increasing demands in building performance and, particularly the ones proposed by the basic document on energy savings [6], are a pressing invitation to search for better building products and systems.

Research conducted by RADEB Research Group at the University of La Rioja intends to analyze and optimize the thermal performance of single-layer ceramic enclosures built with lightweight clay bricks. This work analyzes all the components of a single-layer enclosure, optimizing them until thermal transmittance values are reached that comply with the regulations in force.

A first aspect is to study the possibility of lightening the clay by using additives, reducing the clay's conductivity [7-8] without decreasing its resistive ability. The mineral composition of argillaceous masses used and the different processes that is subjected, together with the additive, influence the thermal conductivity values, density and mechanical strength due to the variation of the porosity of the material [9-11].

A second part of the research involved the study by Finite Element Method (FEM) of internal and external geometry of the bricks in order to optimize the equivalent thermal transmittance of a wall. Likewise, different types of wall assemblies were studied. Analyzed existing studies in the literature on internal geometric distribution, tongue and groove system and different types of assembly [12-18] was concluded that it was possible to optimize them.

\section{OBJECTIVES AND METHODOLOGY}

Figure 1 shows all the components on a perforated clay block that can be adjusted to decrease the equivalent transmittance of an enclosure:

- Thermal conductivity of the clay;

- Internal geometry of the brick;

- External geometry of the brick (Vertical tongue-and-groove joint);

- $\quad$ Type of wall assembly (Horizontal joint).

The first part of the research involves decreasing the thermal conductivity of the clay by adding lightening additives. A lightened clay brick has high macroscopic porosity, and air cells between its clay sheets to prevent the convective flow. In addition, low porosity due to gas bubbles within the clay is generated when the added combustible materials volatilize during firing [19-20].

Several studies have been carried out in order to decrease this conductivity, showing how the additive in the mass decreases its thermal conductivity based on the generation of micropores in the volume of the baked clay [7-8]. The heterogeneity of the materials used and the different set values of the processes render it expedient to conduct more studies to precisely define the variables that influence the outcomes [21-22]. 

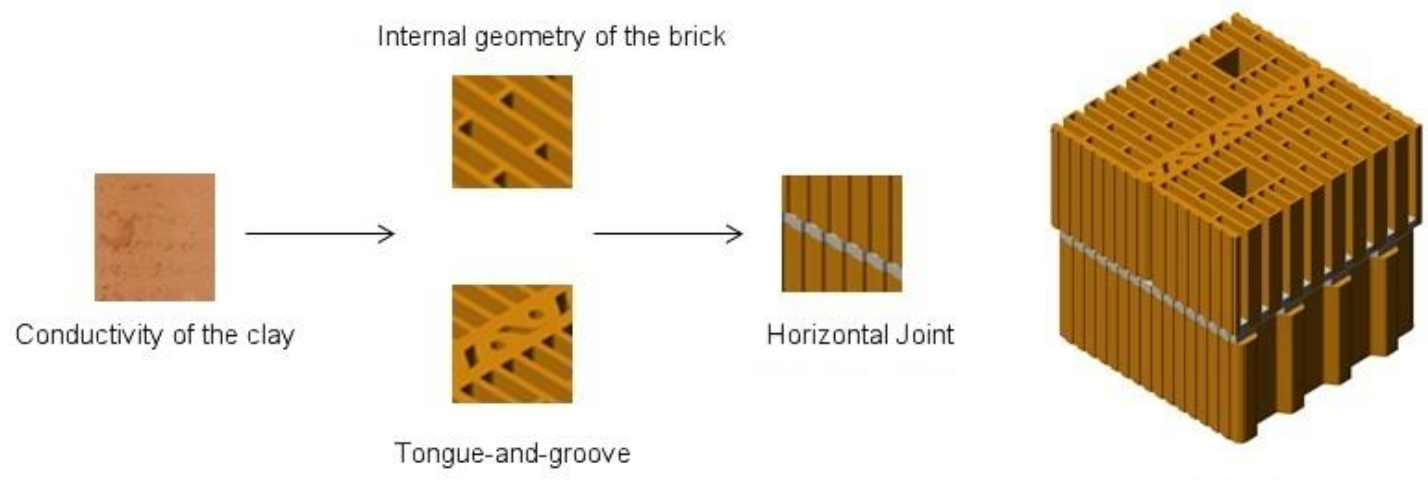

Exterior wall

Fig. 1. Modifiable wall components.

Further cross effects of using lighteners are as follows: firstly, the energy savings due to their use, since the energy dissipated by the lightening materials during spontaneous combustion in the furnace is incorporated into the enthalpy balance inside the firing system, thereby reducing the energy the furnace needs to maintain the temperature; secondly, the elimination of certain wastes from other industries [23-27].

The second part of the research involves applying the finite element method (FEM) to study the internal and external geometry of the lightened clay bricks in order to optimize the equivalent thermal transmittance of a wall. Following an analysis of the existing literature on the interior and exterior geometrical distribution (tongue-andgroove) of the bricks [12, 15-18, 27-29], it has been concluded that its optimization is possible.

The third part studies different types of wall assemblies. As regards walls made with lightened clay bricks, mortars are one of the weakest points due to their thermal bridge effect. For this reason, when using traditional horizontal joints, namely, those with mortars that penetrate into the brick voids, it is important to use lightened mortars with thermal conductivities lower than those of standard mortars, and if this is not possible, it is important to use discontinuous joints, either with air chambers or with an insulating material.

One alternative for traditional horizontal joints is to make thinner joints with bonding mortars. This decreases both the amount of mortar applied and its penetration into the brick voids, minimizing the thermal bridge in the horizontal joint. In this case, the use of a bonding mortar should be considered, which requires a good lay-flat property of the brick in order to ensure a good bonding of the mortar; in other words, rectify the brick.

\section{MATERIALS AND METHODS}

\subsection{Study of the properties of the bricks according to the percentage of additive}

This section studies the conductivity of the clay, based on the addition of a lightening additive, in this case cellulose pulp [28]. In addition, the mechanical properties are studied.

Test samples of the clay were made with cellulose pulp as an additive, taking special care to reproduce the same manufacturing conditions to enable the extrapolation of the results.

The percentages of additive to be tested have been selected based on the experience of the industrial manufacturers. Different percentages from $0 \%$ to $17 \%$ have been chosen to cover the spectrum recommended by prior experience and previous studies, which addressed this additive in a more general manner [30-31].

Five series of six pieces were made, each one with a different percentage $(0 \%, 5 \%, 7 \%, 11 \%$ and $17 \%)$, denoted as AA00, AP05, AP07, AP11 and AP17, respectively.

Considering that the brick's mechanical strength decreases as it is lightened, and in addition to the thermal study of the test samples to find their thermal conductance, it is also necessary to conduct a mechanical study that will show us how far we can lighten the brick while still meeting the regulatory requirements on mechanical resistance [32]. The following studies have therefore been conducted. 


\subsubsection{Thermal studies}

The pieces were first prepared in accordance with EN-771-1:2011 [33]. The thermal conductivity test applied the guarded hot plate and heat-flow meter methods, in accordance with EN 12664-2001 [34], using the WL-376 device manufactured by GUNT [35], according to DIN 52612.

With this test for characterizing the clay pieces, the conductivity value was calculated at $10{ }^{\circ} \mathrm{C}\left(\lambda_{10, \text { dry }}\right)$, all in accordance with EN 1745:2002 [36] (Masonry and masonry products - Methods for determining design thermal values).

\subsubsection{Mechanical Study}

When we consider the type of stresses on the enclosure, we may conclude that the clay piece will be subjected mainly to a compression load resulting from the actual weight of the clay bricks.

For this reason, a compression test was conducted on the test samples used after the thermal conductivity test. We proceeded to randomly select cylinders from among all the test samples by using a rhomboidal bit on a column drill to mill an internal diameter of $19 \mathrm{~mm} \pm 2 \%$.

The pieces, as in all the other tests, have been prepared. Once the test samples are measured in lower/upper height and diameter, they are inserted into a universal compression testing machine built in accordance with EN ISO 7500-1:2004/AC: 2009 [37]. This universal compression-testing machine works with an accuracy of $\pm 1 \%$.

\subsection{Brick geometry}

The study has been conducted with two types of clay: non-lightened clay with a conductivity of $\lambda=0.740 \mathrm{~W} / \mathrm{m} \cdot \mathrm{K}$, and lightened clay with a conductivity of $\lambda=0.50 \mathrm{~W} / \mathrm{m} \cdot \mathrm{K}$, a value only slightly higher than the better conductivity obtained in the previous section. This is a standard value in Europe.

\section{Rectangular voids}

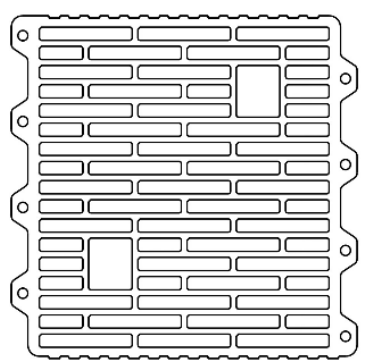

a) Voided tongue-and-groove

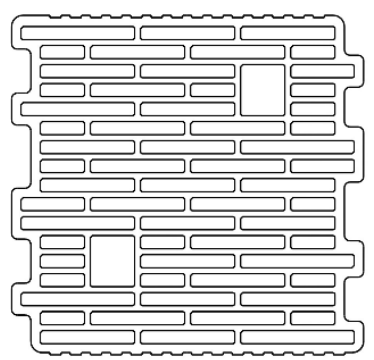

b) Continuous tongue-and-groove

\section{Rhomboidal voids}

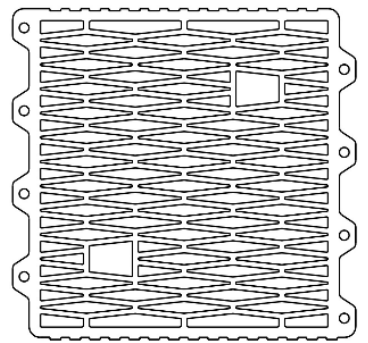

c) Voided tongue-and-groove

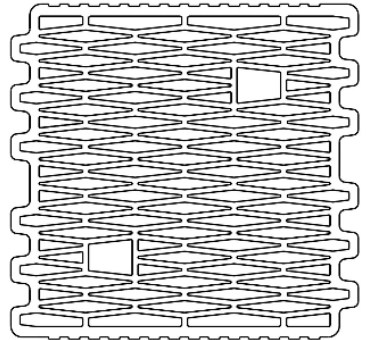

d) Continuous tongue-and-groove

Fig. 2. Block sections.

The brick model under study has the following dimensions ( $\mathrm{Lx} \mathrm{W}$ x H): 300 x 290 x $250 \mathrm{~mm}^{3}$. Four types of bricks have been characterized in this work: one type of brick, with internal rectangular voids, is widely used in buildings and has already been studied [4-5, 12-14] (Figure 2a and 2b), along with a second brick with rhomboidal voids, also previously studied [14-17, 38-39] (Figure 2c and 2d). For these two types of bricks, two types of tongue-andgroove systems have been classified; one with separate circular voids, and one with continuous voids that run from inside the brick to the limit of the tongue-and-groove, which gives continuity to the brick's interior voids. 


\subsection{Wall assembly}

Simultaneously to the study of the brick, we have proceeded to study the different types of wall assembly, calculating the thermal resistance of each cross-section, which reveals the equivalent thermal transmittance of the enclosure [40].

The target model to be analyzed by numeric methods is the part of the wall represented by the assembly of two bricks, as shown in Figure 3, which shows the assembly's three characteristic cross-sections and the height of each one: section of the brick with the voids full of air, called clay-air cross-section (height, $\mathrm{h}_{1}$ ); section of the brick with the voids full of binding mortar, called clay-mortar cross-section (height $h_{2}$ ), and the section called horizontal joint, composed of binding mortar with height, $\mathrm{h}_{3}$.

These heights correspond to a type of standard assembly with binding mortar and penetration into the bricks.

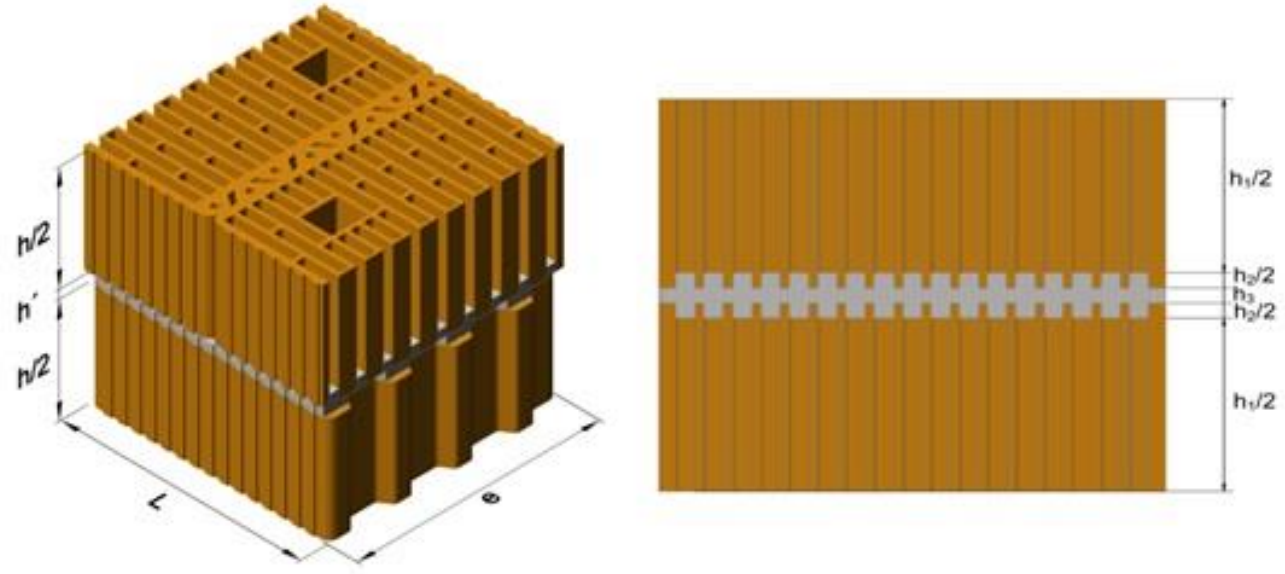

Fig. 3. Section of the wall featuring the assembly of two blocks and the heights of each characteristic crosssection according to standards (AENOR RP 34-14).

The building conditions are as follows: inner coating of plaster, with a thickness of $15 \mathrm{~mm}$ and a conductivity of $0.57 \mathrm{~W} / \mathrm{m} \cdot \mathrm{K}$; outer coating of standard mortar with a thickness of $15 \mathrm{~mm}$ and a conductivity of $1.3 \mathrm{~W} / \mathrm{m} \cdot \mathrm{K}$, and no vertical joint, as it uses a tongue-and-groove arrangement.

Each wall is studied with two types of assembly:

- Traditional assembly using standard mortar $\lambda_{m}=1.3 \mathrm{~W} / \mathrm{m} \cdot \mathrm{K}$, with a discontinuous joint of $30 \mathrm{~mm}$ gap. The penetration, $\mathrm{h}_{2}$, is $20 \mathrm{~mm}$, and the height of the string line, $\mathrm{h}_{3}$, is $10 \mathrm{~mm}$, according to Figure 6 .

- Assembly with thin horizontal joint using bonding mortar $\lambda_{\mathrm{m}}=0.83 \mathrm{~W} / \mathrm{m} \cdot \mathrm{K}$. The assembly has two advantages: there is no penetration into the bricks, i.e., $\mathrm{h}_{2}$ is zero, and the horizontal joint, $\mathrm{h}_{3}$, is $3 \mathrm{~mm}$, since it is a thin joint. This means the characteristic clay-air cross-section has a useful height of $h$ (the sum of $h_{1}$ and $\left.\mathrm{h}_{2}\right)$.

The building's comfort conditions and the calculations of equivalent thermal transmittance, Ueq $\left[\mathrm{W} / \mathrm{m}^{2} \cdot \mathrm{K}\right]$, were obtained in all cases as per the CTE.

\subsection{Thermal calculations}

To conduct this study, heat-flows through the characteristic cross-section of the two-brick assembly are initially obtained by means of FEM [41-42] according to the use of the boundary conditions specified in the relevant standard. This gives the thermal conductivity of the uncoated clay blocks. Although COMSOL gives a relative accuracy of about 16 significant digits, the output results have been recorded with three significant digits.

The thermal calculations are performed according to the following standards: the Spanish UNE CTE [6] and AENOR [43], the European EN [44], and the international ISO 10456:2007 [45]; ISO 8990:1994 [46]; EN 12939:2000 [47]; EN 12664:2001 [34]; EN 1745 [36]; EN ISO 6946 [48], EN ISO 10 211-1 [49] and EN ISO 10 211-2 [50]. 


\section{RESULTS}

\subsection{Results of the Study of Conductivity and Mechanical Resistance}

Figure 4 shows an example of conductivity obtained using the WL-376 device manufactured by GUNT [35].

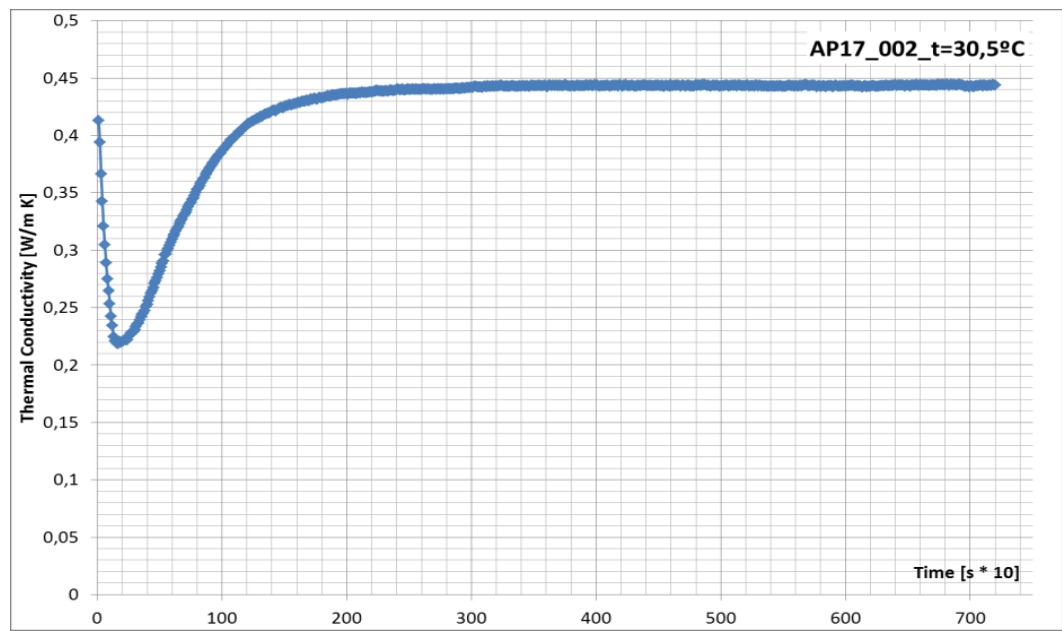

Fig. 4. Example plot of conductivity obtained.

Figure 5 shows an example plot of calculation of $\lambda_{10, \text { dry }}$.

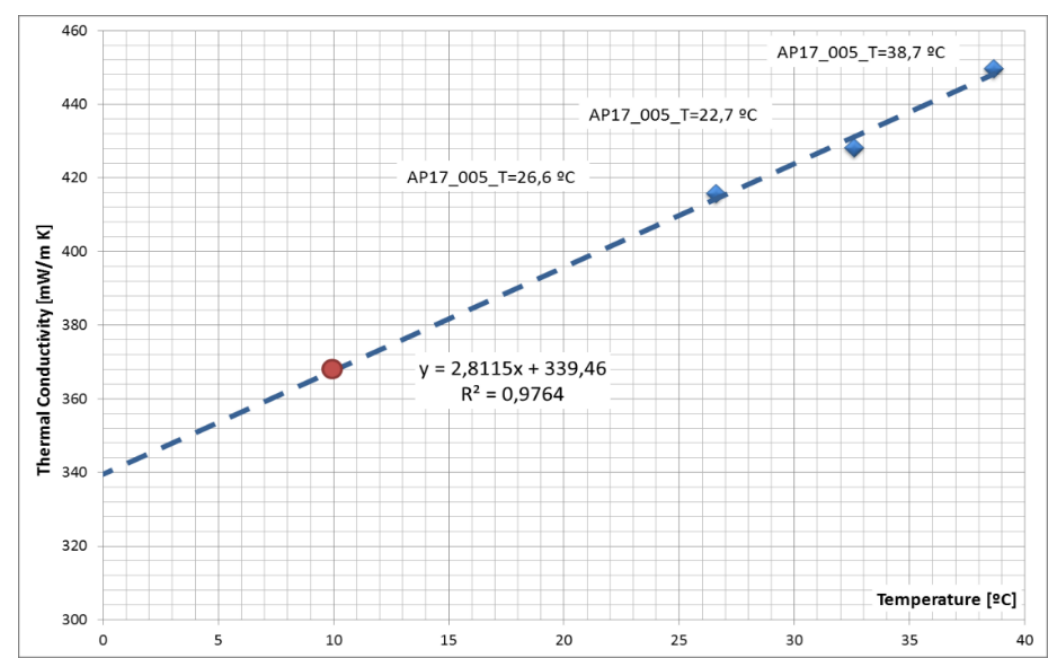

Fig. 5. Calculation of $\lambda_{10, \text { dry }}$, in accordance with EN 1745.

Figure 6 shows an example plot of results of mechanical test.

The full results obtained in both tests are shown in Table 1 . The values correspond to the medians provided by the software Statistica 8, after running the ANOVA. These have used the values of six test samples for each series of percentage of additive.

Table 1. Average values for the series analyzed.

\begin{tabular}{|c|c|c|c|}
\hline Series & $\begin{array}{c}\text { Median breaking stress } \\
{\left[\mathrm{N} / \mathrm{mm}^{2}\right]}\end{array}$ & $\begin{array}{c}\text { Median thermal conductivity } \\
{[\mathrm{W} / \mathrm{m} \cdot \mathrm{K}]}\end{array}$ & $\begin{array}{c}\text { Dry density of the piece } \\
{\left[\mathrm{kg} / \mathrm{m}^{3}\right]}\end{array}$ \\
\hline AA00 & 39.67 & 0.74 & 1,684 \\
\hline AP05 & 31.62 & 0.70 & 1,620 \\
\hline AP07 & 22.69 & 0.64 & 1,574 \\
\hline AP11 & 15.64 & 0.53 & 1,528 \\
\hline AP17 & 7.72 & 0.39 & 1,412 \\
\hline
\end{tabular}




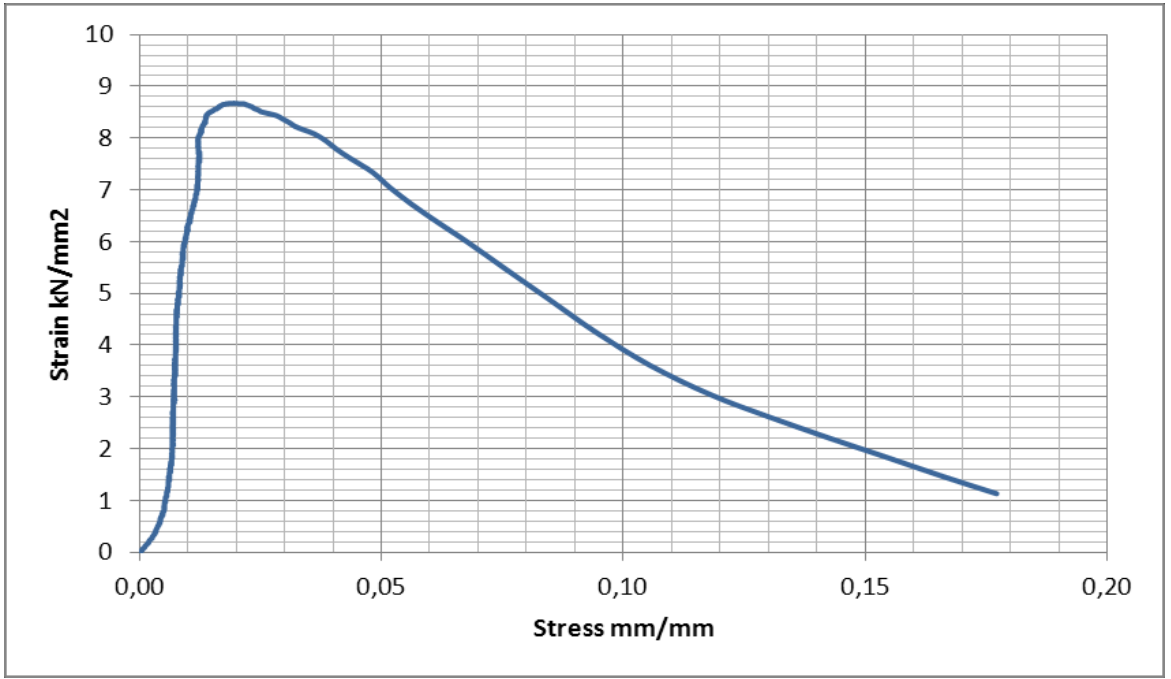

Fig. 6. Example plot of results of mechanical test.

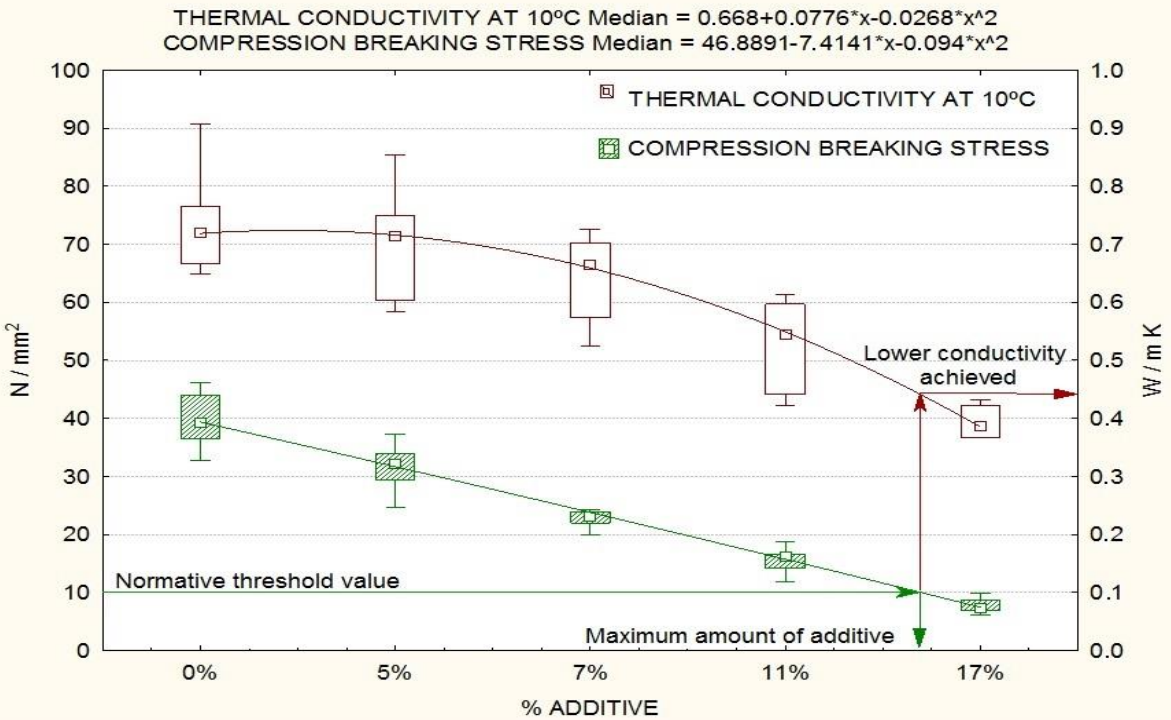

Fig. 7. Comparison of conductivity evolution and breaking stress, showing the minimum admissible value for breaking stress.

Figure 7 features a comparative analysis of the thermal and mechanical behavior according to the percentage of additive. It also shows the normative threshold value, $10 \mathrm{~N} / \mathrm{mm}^{2}$, of the mechanical resistance [6], and the maximum amount of pulp mill. The maximum percentage admissible is approximately $15 \%$, which means a 39.69 $\%$ decrease in the conductivity of clay, obtaining a thermal conductivity of $0.45 \mathrm{~W} / \mathrm{m} \cdot \mathrm{K}$ by extrapolation.

\subsection{Thermal Conductivity Results of Different Bricks with Different Tongue-and-Groove}

The study was carried out with the two types of clay mentioned: lightened clay with conductivity $\lambda=0.50 \mathrm{~W} / \mathrm{m} \cdot \mathrm{K}$, and non-lightened clay with conductivity $\lambda=0.74 \mathrm{~W} / \mathrm{m} \cdot \mathrm{K}$.

Figure 8 shows the heat-flow charts for the characteristic two-brick cross-section assembly for each selected brick made with lightened clay, as an example. It shows the areas with more heat-flow.

It can be clearly seen that a significant thermal bridge occurs in blocks with perforated tongue-and-groove. Similarly, Table 2 shows that the conductivity of bricks with the same interior void and different tongue-and groove is less in the block with continuous tongue-and-groove. 
Both heat-flow charts and the results in Table 2 show that the conductivity of the brick is less in blocks with internal rhomboidal voids, and that the block with the best performance is the one with continuous tongue-andgroove. The same is true of the bricks made with non-lightened clay.

It is also apparent that the conductivity of the brick with the same type of void and clay improves from $10 \%$ to 17 $\%$. A comparison of all the study's alternatives reveals that the total improvement in brick conductivity is $35 \%$.

Surface: Total heat flux $\left[\mathrm{W} / \mathrm{m}^{2}\right]$

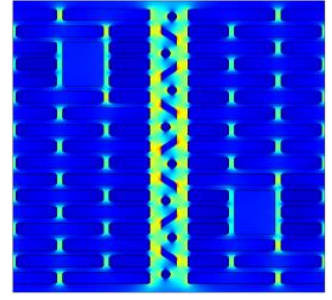

Voided tongue and groove

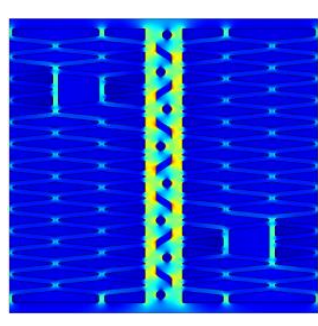

Voided tongue and groove Continues tongue and groove
Fig. 8. Heat-flow chart of clay-air cross-section for the blocks studied.

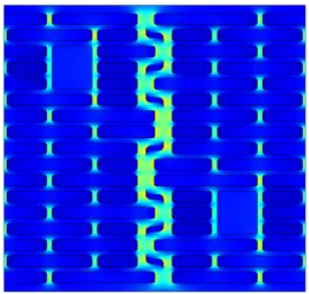

Continues tongue and groove

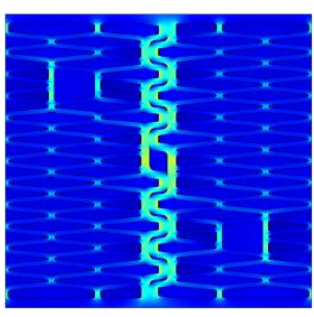

Voided tongue and groove Continues tongue and groove
Fig. 8. Heat-flow chart of clay-air cross-section for the blocks studied.

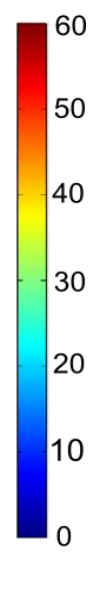

50

40

20

10

Table 2. Conductivity of the brick for each type of block with the two clays selected.

\begin{tabular}{|l|c|c|c|c|}
\hline & \multicolumn{2}{|c|}{$\begin{array}{c}\text { Block with internal rectangular } \\
\text { perforations }\end{array}$} & \multicolumn{2}{c|}{$\begin{array}{c}\text { Block with internal rhomboidal } \\
\text { perforations }\end{array}$} \\
\hline Perforated tongue-and-groove & $\lambda_{\text {clay }}=0.74(\mathrm{~W} / \mathrm{m} \cdot \mathrm{K})$ & $\begin{array}{c}\lambda_{\text {clay }}=0.50 \\
(\mathrm{~W} / \mathrm{m} \cdot \mathrm{K})\end{array}$ & $\begin{array}{c}\lambda_{\text {clay }}=0.74 \\
(\mathrm{~W} / \mathrm{m} \cdot \mathrm{K})\end{array}$ & $\lambda_{\text {clay }}=0.50(\mathrm{~W} / \mathrm{m} \cdot \mathrm{K})$ \\
\hline $\begin{array}{l}\text { Conductivity of the brick } \\
\lambda \text { brick }(\mathrm{W} / \mathrm{m} \cdot \mathrm{K})\end{array}$ & 0.186 & 0.155 & 0.169 & 0.139 \\
\hline $\begin{array}{l}\text { Continuous tongue-and- } \\
\text { groove }\end{array}$ & $\lambda_{\text {clay }}=0.74(\mathrm{~W} / \mathrm{m} \cdot \mathrm{K})$ & $\begin{array}{c}\lambda_{\text {clay }}=0.50 \\
(\mathrm{~W} / \mathrm{m} \cdot \mathrm{K})\end{array}$ & $\begin{array}{c}\lambda_{\text {clay }}=0.74 \\
(\mathrm{~W} / \mathrm{m} \cdot \mathrm{K})\end{array}$ & $\lambda_{\text {clay }}=0.50(\mathrm{~W} / \mathrm{m} \cdot \mathrm{K})$ \\
\hline $\begin{array}{l}\text { Conductivity of the brick } \\
\lambda \text { brick }(\mathrm{W} / \mathrm{m} \cdot \mathrm{K})\end{array}$ & 0.163 & 0.140 & 0.140 & 0.121 \\
\hline
\end{tabular}

\subsection{Thermal Results of the Wall for the Different Arrangements of the Horizontal Joint}

In order to study the influence of the different wall arrangements with the conductivity of the brick and the different types of assembly mentioned, the equivalent thermal transmittance of the wall is calculated. The results are shown in Table 3, revealing the importance of the type of assembly.

Table 3. Table of thermal transmittance of the wall according to the type of block, type of clay and type of assembly.

\begin{tabular}{|l|l|c|c|c|c|}
\hline \multicolumn{2}{|c|}{} & \multicolumn{2}{|c|}{$\lambda_{\text {clay }}=0.74(\mathrm{~W} / \mathrm{m} \cdot \mathrm{K})$} & \multicolumn{2}{|c|}{$\lambda_{\text {clay }}=0.50(\mathrm{~W} / \mathrm{m} \cdot \mathrm{K})$} \\
\cline { 3 - 6 } & \multirow{2}{*}{$\begin{array}{c}30 \mathrm{~mm} \\
\text { discontinuous } \\
\text { air joint }\end{array}$} & Thin joint & \multicolumn{2}{|c|}{$\begin{array}{c}30 \mathrm{~mm} \\
\text { discontinuous air } \\
\text { joint }\end{array}$} & Thin joint \\
\hline $\begin{array}{l}\text { Rectangular } \\
\text { internal } \\
\text { perforations }\end{array}$ & Perforated tongue-and-groove & 0.718 & 0.591 & 0.625 & 0.506 \\
\cline { 2 - 6 } & Continuous tongue-and-groove & 0.661 & 0.528 & 0.588 & 0.465 \\
\hline & Perforated tongue-and-groove & 0.668 & 0.544 & 0.574 & 0.462 \\
\hline
\end{tabular}




\begin{tabular}{|l|l|c|c|c|c|}
\hline $\begin{array}{l}\text { Rhomboidal } \\
\text { internal } \\
\text { perforations }\end{array}$ & Continuous tongue-and-groove & 0.598 & 0.466 & 0.529 & 0.410 \\
\hline
\end{tabular}

In the thin joint assembly where the mortar joint is smaller, the equivalent thermal transmittance of the wall decreases significantly. It follows that, for the same block and clay, decreasing the horizontal joint from $10 \mathrm{~mm}$ to $3 \mathrm{~mm}$ and eliminating the clay-mortar cross-section in an assembly with a thin joint decreases the thermal transmittance of the wall by $18-22 \%$, depending on the type of block used.

If we now compare what improves the equivalent thermal transmittance of the wall among all the alternatives studied, we notice that the improvement achieved is significant, $43 \%$. These results show how important it is to optimize all the variables studied, the conductivity of the clay, the type of geometry of the clay block, and the type of assembly.

\section{CONCLUSIONS}

By adding $15 \%$ of pulp mill to the clay studied, we can decrease thermal conductivity from $0.74 \mathrm{~W} / \mathrm{m} \cdot \mathrm{K}$ to 0.45 $\mathrm{W} / \mathrm{m} \cdot \mathrm{K}$, which is an increase of $40 \%$ in clay conductivity. This is the minimum thermal conductivity value we can obtain with the clay, and using bricks as structural elements.

The usefulness of the additive indirectly leads to a reappraisal of the waste generated by paper industries, which means a reduction in its environmental impact. Similarly, the energy contribution of the additive itself decreases the amount of energy required for firing.

For the four blocks studied, with rectangular and rhomboidal voids and perforated or continuous tongue-andgroove voids, and the two clays studied, a clay conductivity of $0.121 \mathrm{~W} / \mathrm{m} \cdot \mathrm{K}$ was obtained, recording a $35 \%$ of improvement.

When studying the type of wall assembly, we became aware of the considerable importance of the thin joint type. With this type of assembly, the improvement in the wall's equivalent thermal transmittance, for the same type of block and the same clay, ranged between $18 \%$ and $22 \%$.

If we also take into consideration the type of block and the type of clay, the improvement in the equivalent thermal transmittance of the wall is $43 \%$, may conclude by stressing the importance of optimizing all the variables studied in order to save energy in buildings by improving the type of enclosure. Adding lightening additives to the clay improves its conductivity. The type of internal and external geometry of the clay block improves brick conductivity, and optimizing the type of assembly in turn improves the wall's equivalent thermal transmittance. By optimizing all the variables studied, the equivalent thermal transmittance of the enclosure obtained was 0.410 $\mathrm{W} / \mathrm{m}^{2} \cdot \mathrm{K}$

\section{REFERENCES}

[1] Theodosiou, T.G.; Papadopoulos, A.M., The impact of thermal bridges on the energy demand of buildings with double brick wall constructions, Energy and Buildings, vol. 40, no. 11, 2007, p. 2083-2089. http://dx.doi.org/10.1016/j.enbuild.2008.06.006.

[2] http://ec.europa.eu/eurostat/documents/3217494/7052812/KS-DK-15-001-EN-N.pdf; Eurostat 2015, Energy, transport and environment indicators, ISSN 2363-2372. (online data code: nrg_110a).

[3] Raimondo, M., Dondi, M., Mazzanti, F., Stefanizzi, P., Bondi, P., Equilibrium moisture content of clay bricks: The influence of the porous structure, Building and Environment, vol. 42, no. 2, 2007, p. 926-932. http://dx.doi.org/10.1016/j.buildenv.2005.10.017.

[4] Antar, M.A., Thermal radiation role in conjugate heat transfer across a multiple-cavity building block, Energy, vol. 35, 2010, p. 3508-3516. http://dx.doi.org/10.1016/j.energy.2010.04.055.

[5] Garcia, X., Idoneidad de los cerramientos monocapa para viviendas Bioclimaticas en emplazamientos de elevada severidad climatica, Universidad Pontificia Comillas de Madrid, Instituto de Investigacion Tecnologica, 2003. http://www.iit.upco.es.

[6] Codigo Tecnico de la Edificacion, Documento Basico, Ahorro de Energia, CTE-DB-HE, Norma Espanola, 2006. http://www.codigotecnico.org. 
[7] Herek Luciana, C.S., Hori, C.E., Miranda Reis, M.H., Diaz Mora, N., Granhem Tavares, C.R., Bergamasco, R., Characterization of ceramic bricks incorporated with textile laundry sludge, Ceramics International, vol. 38, no. 2, 2012, p. 951-959. http://dx.doi.org/10.1016/j.ceramint.2011.08.015.

[8] Topçu, I.B., Isikdag, B., Manufacture of high heat conductivity resistance clay bricks containing perlite, Building and Environment, vol. 42, no. 10, 2007, p. 3540-3546. http://dx.doi.org/10.1016/j.buildenv.2006.10.016. [9] O'Farrell, M., Wild, S., Sabir, B.B., Pore size distribution and compressive strength of waste clay bricks mortar, Cement \& Concrete Composites, vol. 23, no. 1, 2001, p. 81-91. http://dx.doi.org/10.1016/S0958-9465(00)000706.

[10] Cultrone, G., et al., Influence of mineralogy and firing temperature on the porosity of bricks, ECERS 24, 2004, p. 547-564. http://dx.doi.org/10.1016/S0955-2219(03)00249-8.

[11] Freyburg, S., Schwarz, A., Influence of the clay type on the pore structure of structural ceramics, ECERS 27, vol. 2-3, 2007, p. 1727-1733. http://dx.doi.org/10.1016/j.eurceramsoc.2006.04.158.

[12] Sastre, V., Con arquitectura, "Bloques ceramicos de alto aislamiento térmico, Termoarcilla ECO”, 2008. http://conarquitectura.com/articulos\%20tecnicos\%20pdf/26.pdf.

[13] Consorcio de termoarcilla \& Labein Tecnalia, "Investigación de las condiciones del Bloque Termoarcilla para el cumplimiento de las exigencias del nuevo CTE. Propiedades térmicas", 2005.

[14] Li, L.P., Wu, Z.G., He, Y.L., Lauriat, G., Tao, W.Q., Optimization of the configuration of $290 \times 140 \times 90$ hollow clay bricks with 3-D numerical simulation by finite volume method, Energy and Buildings, vol. 40, no. 10, 2008, p. 1790-1798. http://dx.doi.org/10.1016/j.enbuild.2008.03.010.

[15] Lourenco, P.B., Vasconcelos, G., Medeiros, P., Gouveia, J., Vertically perforated clay brick masonry for loadbearing and non-loadbearing masonry walls. Construction and Building Materials, vol. 24, 2010, p. 23172330. http://dx.doi.org/10.1016/j.conbuildmat.2010.04.010.

[16] Del Coz Diaz, J.J., Neto, P.J.G., Sierra, J.L.S., Biempica, C.B., Nonlinear thermal optimization of external light concrete multi-holed brick walls by finite element method. International Journal of Heat and Mass Transfer, vol. 51, 2008, p. 1530-1541. http://dx.doi.org/10.1016/j.ijheatmasstransfer.2007.07.029.

[17] Li, L.P., Wu, Z.G., He, Y.L., Lauriat, G., Tao, W.Q., Numerical thermal optimization of the configuration of multi-holed clay bricks used for constructing building walls by the finite volume method. International Journal of Heat and Mass Transfer, vol. 51, 2008, p. 3669-3682. http://dx.doi.org/10.1016/j.ijheatmasstransfer.2007.06.008. [18] Ghazi Wakili, K., Tanner, Ch., (2003) U-value of a dried wall made of perforated porous clay bricks: Hot box measurement versus numerical analysis, Energy and Buildings, vol. 35, no. 7, 2003, p. 675-680. http://dx.doi.org/10.1016/S0378-7788(02)00209-8.

[19] Calabria, J.A., Vasconcelos, W.L., Boccaccini, A.R., Microstructure and chemical degradation of adobe and clay bricks, Ceramics International, vol. 35, no. 2, 2008, p. 665-671. http://dx.doi.org/10.1016/j.ceramint.2008.01.026.

[20] Oti, J.E., Kinuthia, J.M., Bai, J., Design thermal values for unfired clay bricks, Materials \& Design, vol. 31, no. 1, 2009, p. 104-112. http://dx.doi.org/10.1016/j.matdes.2009.07.011.

[21] Sutcu, M., Akkurt, S., Utilization of recycled paper processing residues and clay of different sources for the production of porous anorthite ceramics, ECERS, vol. 30, no. 8, 2010, p. 1785-1793. http://dx.doi.org/10.1016/i.jeurceramsoc.2010.01.038.

[22] Machado, A.T., Valenzuela-Diaz, F.R., De Souza, C.A.C., De Andrade Lima, L.R.P., Structural ceramics made with clay and steel dust pollutants, Applied Clay Science, vol. 51, no. 4, 2011, p. 503-506. http://dx.doi.org/10.1016/j.clay.2011.01.004.

[23] Bilgin, N., Yeprem, H.A., Arslan, S., Bilgin, A., Gunay, E., Marsoglu, M., Use of waste marble powder in brick industry, Construction and Building Materials, vol. 29, 2012, p. 449-457. http://dx.doi.org/10.1016/j.conbuildmat.2011.10.011.

[24] Dondi, M., Guarini, G., Raimondo, M., Zanelli, C., Recycling PC and TV waste glass in clay bricks and roof tiles, Waste management, vol. 29, 2009, p.1945-1951, http://dx.doi.org/10.1016/j.wasman.2008.12.003.

[25] Raut, S.P., Ralegaonkar, R.V., Mandavgane, S.A., Development of sustainable construction material using industrial and agricultural solid waste: A review of waste-create bricks, Construction and Buildings Materials, vol. 25, no. 10, 4037, 2011, p. 40-42, http://dx.doi.org/10.1016/j.conbuildmat.2011.04.038.

[26] Zhang, L., Production of bricks from waste materials-A review, Construction and Building Materials, vol. 47 , 2013, p. 643-655. http://dx.doi.org/10.1016/j.conbuildmat.2013.05.043.

[27] Li, L.P., Wu, Z.G., He, Y.L., Lauriat, G., Tao, W.Q., Optimization of the configuration of $290 \times 140 \times 90$ hollow clay bricks with 3-D numerical simulation by finite volume method, Energy and Buildings, vol. 40, no. 10, 2008, p. 1790-1798. http://dx.doi.org/10.1016/i.enbuild.2008.03.01.

[28] Munoz, P., Juarez, M.C, Morales, M.P., Mendivil, M.A., Improving the thermal transmittance of single-brick wall built of clay bricks lightened with paper pulp, Energy \& Buildings, vol. 59, 2013, p. 171-180, http://dx.doi.org/10.1016/j.enbuild.2012.12.022. 
[29] Li, L.P., Wu, Z.G., He, Y.L., Lauriat, G., Tao, W.Q., Numerical thermal optimization of the configuration of multi-holed clay bricks used for constructing building walls by the finite volume method. International Journal of Heat and Mass Transfer, vol. 51, 2008, p. 3669-3682, http://dx.doi.org/10.1016/j.ijheatmasstransfer.2007.06.008. [30] Demir, I., Serhat Baspinar, M., Orhan, M., Utilization of kraft pulp production residues in clay brick production, Building and Environment, vol. 40, no. 11, 2005, p. 1533-1537, http://77dx.doi.org/10.1016/j.buildenv.2004.11.021.

[31] Demir, I., An investigation on the production of construction brick with processed waste tea. Building and Environment, vol. 41, 2006, 1274-1278, http://dx.doi.org/10.1016/j.buildenv.2005.05.004.

[32] Codigo Tecnico de la Edificacion, Documento Basico, Seguridad Estructural, CTE. DB-SE-F, Norma Espanola, 2006, http://www.codigotecnico.org

[33] European Standard, EN 771-1:2011. Specification for masonry units - Part 1: Clay masonry units, 2011.

[34] European Standard, EN 12664:2001, thermal performance of building materials and products - determination of thermal resistance by means of guarded hot plate and heat flow meter methods - dry and moist products of medium and low thermal resistance. European Committee for Standardization, 2001.

[35] Website of the Thermal Test Machine: www.gunt.de.

[36] European Standard, EN 1745:2002, "Masonry and masonry products. Methods for determining design thermal values".

[37] European Standard, EN ISO 7500-1:2004/AC: 2009 Metallic materials - Verification of static uniaxial testing machines - Part 1: Tension/compression testing machines - Verification and calibration of the force-measuring system, 2009.

[38] Morales, M.P., Juarez, M.C., Munoz, P., Gomez, J.A., Study of the geometry of a voided clay brick using non-rectangular perforations to optimise its thermal properties, Energy and Building, vol. 43, no. 9, 2011, p. 24942498. http://dx.doi.org/10.1016/j.enbuild.2011.06.006.

[39] Morales, M.P., Juarez, M.C., Lopez-Ochoa, L.M., Munoz, P., Influence of tongue and groove system on the thermal properties of large-format voided clay bricks for single-leaf walls, Construction and Building Materials, vol. 30, 2012, p. 169-173, http://dx.doi.org/10.1016/j.conbuildmat.2011.12.006.

[40] Juarez, M.C., Morales, M.P., Munoz P., Gomez, J.A., Influence of horizontal joint on the thermal properties of single-leaf walls with lightweight clay blocks, Energy and Buildings, vol. 49, 2012, p. 362-366. http://dx.doi.org/10.1016/j.enbuild.2012.02.033.

[41] COMSOL 4.2a, Multiphysics modeling and engineering simulation software, [CD ROM] COMSOL AB; 2011, http://www.comsol.com

[42] ANSYS 14.0, Multiphase Modeling and Engineering Simulation Software, 2012, http://www.ansys.com.

[43] Spanish Standard. Reglamento particular de la marca AENOR para piezas de arcilla cocida para fabricas a revestir. AENOR RP 34-14, 2009, http://www.aenor.es/documentos/certificacion/reglamentos/w_RP 3414 2009-06-01.pdf.

[44] European Standard, EN 12939:2000, Thermal performance of building materials and products - determination of thermal resistance by means of guarded hot plate and heat flow meter methods - thick products of high and medium thermal resistance, European Committee for Standardization, 2000.

[45] International Standard, ISO 10456:2007 Building materials and products. Procedures for determining declared and design thermal values, 2007, http://www.iso.org/iso/catalogue detail.htm\%3Fcsnumber=40966 (Accessed February 2016).

[46] International Standard, ISO 8990:1994/2006. p. 50748. Thermal insulation - determination of steady-state thermal transmission properties - calibrated and guarded hotbox, 2006.

[47] European Standard, EN 12939:2000, Thermal performance of building materials and products - determination of thermal resistance by means of guarded hot plate and heat flow meter methods - thick products of high and medium thermal resistance. European Committee for Standardization, 2000.

[48] European and International Standard, EN ISO 6946:1996, Building components and building elements. Thermal resistance and thermal transmittance. Calculation method, 1996.

[49] European and International Standard, EN ISO 10 211-1:1995, Thermal bridges in building construction. Heat flows and surface temperatures. Part 1: General calculation methods, 1995.

[50] European and International Standard, EN ISO 10 211-2:2002, Thermal bridges in building construction. Heat flows and surface temperatures. Part 2: Thermal linear bridges, 2002. 